\title{
Suitability of Seagrass Ecosystem for Marine Ecotourism in Padang City, West Sumatera Province
}

\author{
Try Al Tanto ${ }^{1, *}$, Aprizon Putra ${ }^{1,2}$, Dedi Hermon ${ }^{2}$, Harfiandri Damanhuri ${ }^{3}$ \\ ${ }^{1}$ Research Institute for Coastal Resources and Vulnerability, Padang 25245 - Indonesia \\ ${ }^{2}$ Department of Geography, Padang State University, Padang 25132 - Indonesia \\ ${ }^{3}$ Faculty of Fisheries and Marine Science, Bung Hatta University, Padang 25133 - Indonesia \\ *) Corresponding Author (e-mail: try.altanto@gmail.com)
}

Received: 30 October 2017/ Accepted: 08 December 2017 / Published: 06 July 2018

\begin{abstract}
Seagrass ecosystems are exciting parts of the tropical coastal region that are potential for ecotourism activities. Marine ecotourism sector in the city of Padang has begun to develop within last few years. This development has not only positive impacts but also negative threats to the environment. Therefore, carefully select the most suitable areas for this purpose is important. This article aims to propose the potential areas for seagrass ecotourism in Padang city based on Geographic information system (GIS) analysis. We used spatial analysis to develop the seagrass ecotourism suitability index that is also potentially applicable to other areas. The results of the analysis show that area of the seagrass ecosystem in Nirwana beach ( 23.75 ha), Cindakir beach (2.56 ha), and Pasumpahan island (5.46 ha) with a total area of the seagrass ecosystem overall in Padang City ( 31.78 ha). These areas have been overgrown by Thalassia hemprichii with coverage $>50-75 \%$ in Nirwana beach, $25-50 \%$ in Cindakir beach and Pasumpahan Island. The suitable areas for seagrass ecotourism were found on the beach of Nirwana (covers $84 \%$ as very suitable), Cindakir beach (covers $73 \%$ as moderately suitable) and Pasumpahan island (covers $78 \%$ as moderately suitable). We found that activities of local communities decreased the suitability of Cindakir beach and Pasumpahan island because these activities increase the abundance of mud in the substrate of waters.
\end{abstract}

Keywords: seagrass ecotourism suitability index, seagrass ecosystem, marine ecotourism, Padang city, GIS.

\begin{abstract}
Abstrak. Salah satu pemanfaatan kawasan pesisir adalah untuk kegiatan ekowisata, diantaranya seperti ekowisata lamun. Dalam beberapa tahun terakhir, pembangunan kawasan pesisir Kota Padang di sektor ekowisata laut sudah mulai berkembang. Di sisi lain, berbagai aspek pengembangan ekowisata laut pasti berdampak positifatau negatif dan mengancam lingkungan. Tujuan dari penelitian ini adalah untuk menilai kesesuaian ekowisata lamun di kawasan pesisir dan pulau-pulau kecil di Kota Padang. Metode penelitian yang digunakan adalah analisis indeks kesesuaian untuk ekowisata lamun dengan pendekatan Sistem Informasi Geografis (SIG). Hasil analisis data penelitian menunjukkan luas ekosistem lamun di pantai Nirwana $(23,75 \mathrm{ha})$, pantai Cindakir (2,56 ha), dan pulau Pasumpahan (5,46 ha) dengan total luas ekosistem lamun secara keseluruhan di Kota Padang (31,78 ha). Jenis lamun yang ditemukan adalah Thalassia hemprichii dengan tutupan lamun meliputi $>50$ - $75 \%$ di pantai Nirwana, 25 - 50 \% di pantai Cindakir dan Pulau Pasumpahan. Ekowisata lamun di pantai Nirwana masuk dalam kategori sangat sesuai (S1) dengan nilai 84\% dan cukup sesuai (S2) di pantai Cindakir dengan nilai 73 $\%$ dan pulau Pasumpahan dengan nilai 78 \%. Kriteria yang cukup sesuai di pantai Cindakir dan pulau Pasumpahan dikarenakan substrat perairan sebagian besar adalah pasir berpasir dan berlumpur, dimana pasir berlumpur disebabkan oleh kegiatan lingkungan dan aktivitas masyarakat setempat.
\end{abstract}

Kata Kunci: indeks kesesuain ekotourism, Ekosistem Lamun, Ekowisata Laut, Kota Padang, SIG. 

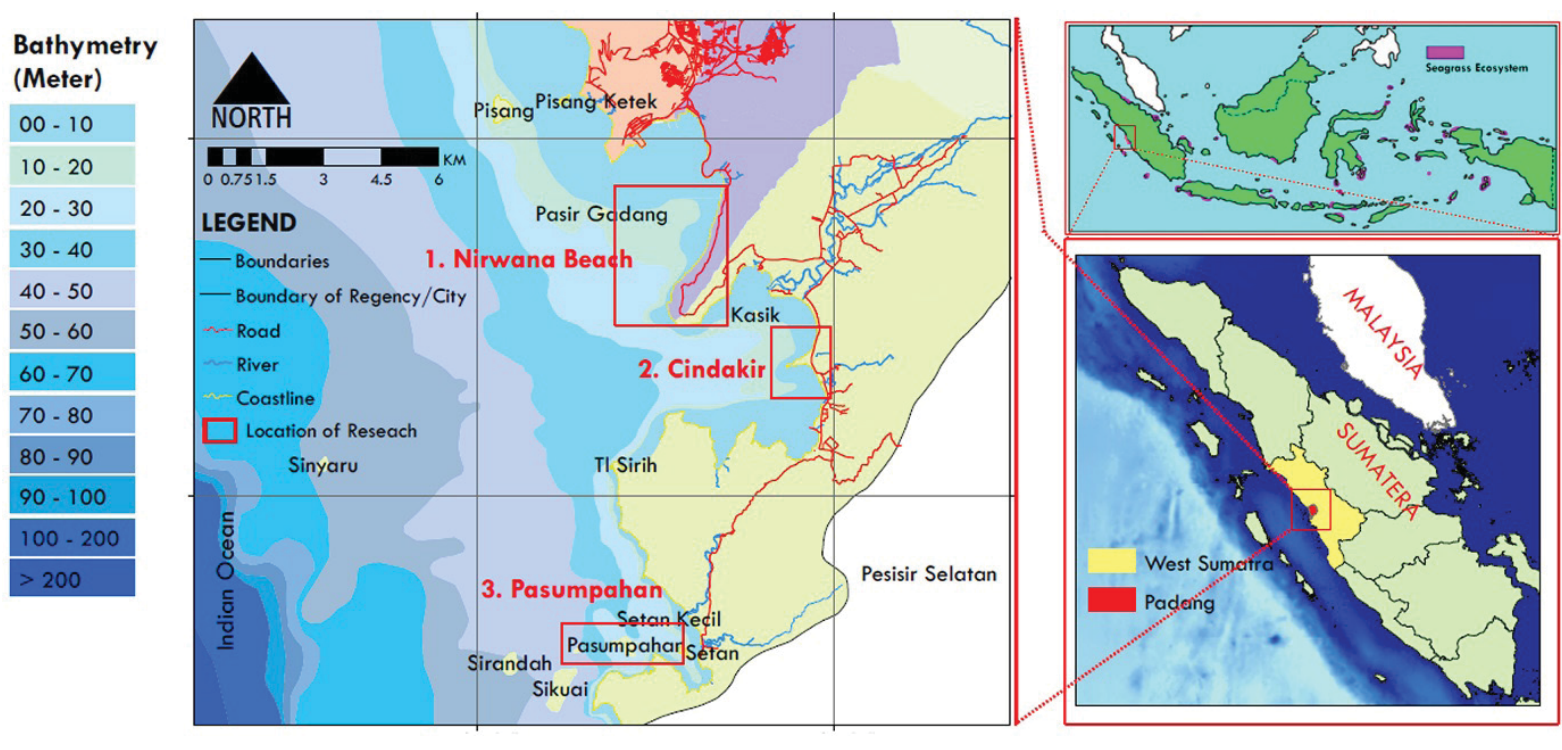

Figure 1. Map of Research location

Table 1. Suitability Matrix for the Seagrass Ecotourism.

\begin{tabular}{lccccc}
\hline \multirow{2}{*}{ Parameter } & \multirow{2}{*}{ Weight } & \multicolumn{4}{c}{ Value of suitability } \\
\cline { 3 - 6 } & & S1 (Score 4) & S2 (Score 3) & S3 (Score 2) & N (Score 1) \\
\hline Seagrass coverage (\%) & 5 & $>75$ & $>50-75$ & $25-50$ & $<2$ \\
Waters brightness (m) & 4 & $>10$ & $>5-10$ & $3-5$ & $<2$ \\
Fish species & 4 & $>10$ & $6-10$ & $3-5$ & $<3$ \\
Seagrass species & 4 & Cymodocea, & Syringodium & Thalassia & Enhrichii \\
Substrate type & 3 & Halophila & Sand & muddy sand & muddy \\
Current velocity & 3 & $0-15$ & $>15-30$ & $>30-50$ & $>50$ \\
Seagrass depth & 3 & $1-3$ & $>3-6$ & $6-10$ & $>10$ \\
\hline
\end{tabular}

Source: Modified from Yulianda (2007).

\section{Introduction}

Seagrass is a unique plant with specific habitat under saline water. This is the only flowering plant (angiosperms) which is able to grow in saline waters. The plant is immersed in water but has rhizome, leaves and true roots. The seagrass thrives under-waters up to 4 metres which is mainly in open areas of tides and coastal waters. The seabed where seagrass living usually consist of mud, sand, gravel, or organic debris (Kennish et al., 2008). As part of the food chain of aquatic life, damage and loss of the seagrass means to break the chain of life Kordi (2011).

The habitat of seagrass with various types is concentrated in two main regions, namely the Indo-Pacific and the Central America beaches. Seagrass plants in the world consist of 2 families, 12 genus with 49 species. The
12 genus 7 of them live in tropical waters, namely Enhalus, Thalassia, Halophila, Holodule, Cymodocea, Syringodium, and Thalassodendron. In Indonesia 13 species were found. Whereas Thalassia hemprichii is the most dominant species in Indonesian's waters. Seagrass ecosystem becomes interesting because of its uniqueness, therefore, it is potential for coastal tourism (Wardani et al., 2007).

Lately, the demand of such coastal tourism by foreign tourists in Indonesia increases. Therefore, it needs protection of marine conservation agency. This type of activities are commonly known as ecotourism, or today is better known as ecotourism that is tourism with an orientation to the objects of natural resource conservation and environmental education ( $\mathrm{Li}$ et al., 2014). Based on The Ecotourism Society, ecotourism is a form of travel to natural areas 
with the aim of conserving the environment and preserve the life and well-being of residents (Fandeli, 2000). While according to Haryati (2010) real ecotourism is a combination of different interests that are growing by the environmental, economic, and social concerns.

Ecotourism has potential to develop the economic aspect. Therefore, adequate management of the coastal region is expected to provide benefit and improve the level of welfare for the community. The management of coastal region should be followed by the development of multiple aspects that are directly and indirectly related to the activities (Marfai et al., 2013). Therefore, integrated management of the coastal region is required which must be preceded by several scientific studies (Sugandi, 2013). The studies should comprise a study on the marine ecosystem, water quality and ecotourism potential. As part of such studies, this research focus on the last aspect which is the potential of marine ecosystem for seagrass ecotourism in Padang City, Indonesia. This study purposed to assess the suitability of the seagrass ecotourism in the coastal region and small islands in Padang City. This research is based on spatial analysis which overlaid several datasets by scoring approach. The detail of the study area, methodology and the results are provided in the following sections.

\section{Research Method}

\subsection{Study Area}

Padang City has $\pm 84 \mathrm{~km}$ long of coastline which covers waters authority area of 72,000 ha and 19 small islands within this area. Padang City has high potential ecotourism for the coastal region and small islands, especially the seagrass ecotourism as part of efforts to strengthen the marine ecotourism activities. The research location is conducted in the waters of Nirwana beach $\left(1^{\circ} 1^{\prime} 39.48^{\prime \prime} \mathrm{S}\right.$ - $\left.100^{\circ} 23^{\prime} 4.55^{\prime \prime} \mathrm{E}\right)$, the waters of Cindakir beach $\left(1^{\circ} 3^{\prime} 14.55^{\prime \prime} \mathrm{S}-100^{\circ} 24^{\prime} 18.08^{\prime \prime} \mathrm{E}\right)$ and the waters of Pasumpahan island (1 $1^{\circ} 4.27^{\prime \prime} \mathrm{S}$ $100^{\circ} 22^{\prime} 10.34^{\prime \prime}$ ) Padang City, West Sumatera Province (Figure 1). Monitoring the seagrass ecosystem was done using transects of $1 \times 1$ $\mathrm{m}$ sized-square at the location of the seagrass in coastal waters (Tanto et al., 2014). These transects are located at Nirwana beach, Cindakir beach, and Pasumpahan island. At these locations, in addition to the sampling of the seagrass cover, we also made tracking to determine the seagrass location.

\subsection{Suitability Analysis of the Seagrass Ecotourism}

Marine ecotourism activities can be classified as coastal tourism and marine tourism (Hermon, 2016). For the development of marine ecotourism in the coastal region and small islands in Padang City, we need to assess the potential of location (including the existing condition) and the suitability of the original condition (naturally). We used Equation 1 to assess the suitability of the seagrass ecotourism.

$\mathrm{ESI}=\sum\left(\frac{\mathrm{Ni}}{\mathrm{N}_{\max }}\right) \times 100 \%$

ESI = Ecotourism Suitability Index.

$\mathrm{N}_{\mathrm{i}} \quad=$ Parameter value to-i (weights $\mathrm{x}$ Score).

$\mathrm{N}_{\max }=\mathrm{A}$ maximum value of ecotourism category.

Data analysis using Geographic Information System (GIS) based on suitability matrix for the seagrass ecotourism (Yulianda, 2007). This matrix is composed based on seven suitability parameters: 1) the seagrass cover, 2) water brightness, 3) fish species, 4) the seagrass species, 5) substrate type, 6) current velocity, and 7) the seagrass. Each parameter is assigned with weight, while each class of the value of each parameter is assigned with a score. Consequently, the total score is the aggregate of multiplication of score and weight (Taslim et al., 2014). For more details, the matrix of suitability for the seagrass of ecotourism can be seen in Table 1. The result of this calculation range from 26 to 104 . This scoring results were classified into SS = highly suitable (total score $80-100 \%$ ), S= suitable (total score $60-<80 \%$ ), $\mathrm{SB}=$ conditionally suitable (total score $35-<$ $60 \%$ ), $\mathrm{N}=$ not suitable (total score $<35 \%$ ). 
Table 2. Species of Fish on the Seagrass Ecosystem at the Research Location.

\begin{tabular}{|c|c|c|c|c|}
\hline \multirow{2}{*}{ Families } & \multirow{2}{*}{ Species } & \multicolumn{3}{|c|}{ Location } \\
\hline & & 1 & 2 & 3 \\
\hline \multirow{7}{*}{ Gobiidae } & Periophthalmus sp & + & - & + \\
\hline & Pseudogobius javanicus & + & + & + \\
\hline & Pandaka sp & + & + & + \\
\hline & Periopthalmus Argentilineatus & + & - & + \\
\hline & Glossogobius biocellatus & - & - & + \\
\hline & Glossogobius giuris & - & - & + \\
\hline & Oxyurichthys sp & + & - & + \\
\hline \multirow{2}{*}{ Chandidae } & Ambassis urotaenia & + & - & + \\
\hline & Ambassis sp & + & - & + \\
\hline Fistulariidae & Fistularia commersonii & + & + & + \\
\hline Apogonidae & Apogon hyalosom & + & - & + \\
\hline Oryziidae & Oryzias javanicus & + & - & + \\
\hline Atherinidae & Atherinomorus lacunosus & + & - & + \\
\hline Leiognathidae & Leiognathus decorus & + & - & + \\
\hline Scatophagidae & Scatophagus argus & + & - & + \\
\hline
\end{tabular}
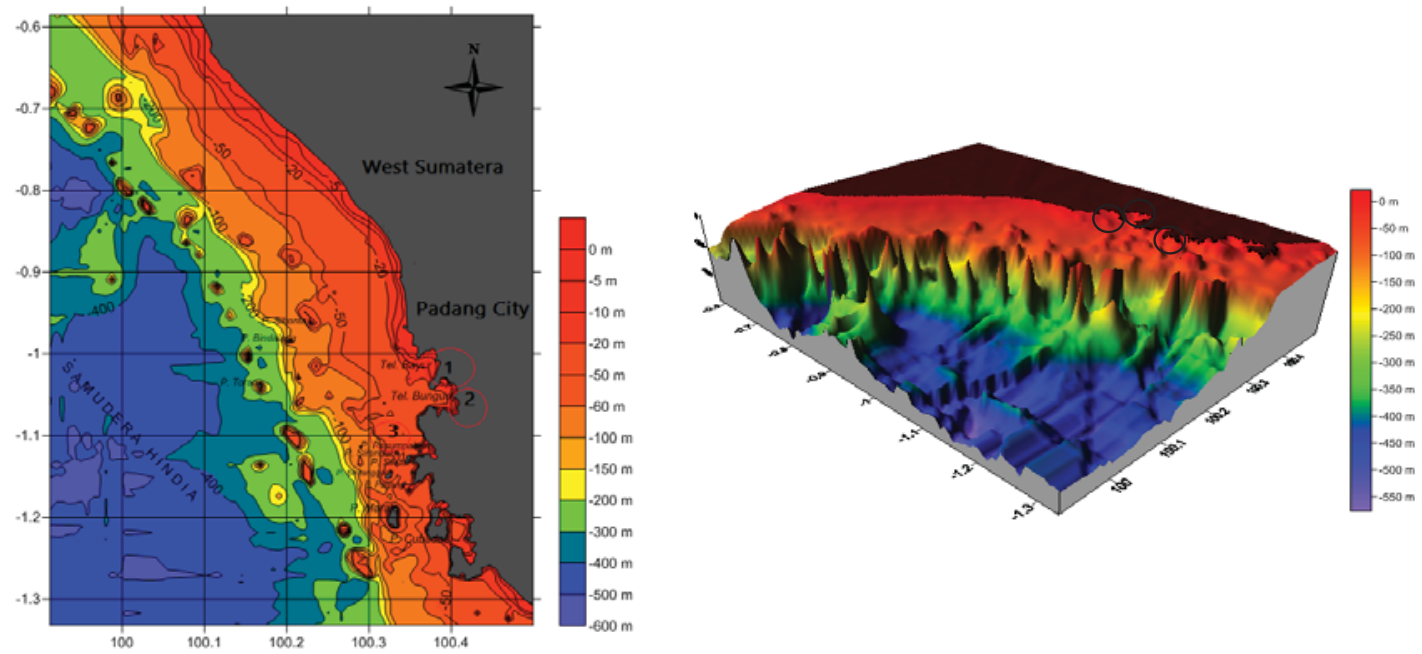

Figure 2. 2D Map and 3D Map of Waters Depth in Padang City and its Surroundings.

\section{Results and discussion}

The seagrass ecosystems areas on the coastal and small islands in Padang City can be divided into 3 locations i.e. location 1 is located on Nirwana beach of Lubuk Begalung sub-district, location 2 is located on Cindakir beach, and location 3 is located on Pasumpahan island of Bungus Teluk Kabung sub-district. The further description and analysis of the suitability assessment will be based on these location segmentations. Meanwhile, the description of the characteristics of each location is based on the seven parameters as presented in Table 1.

\subsection{Characteristics of Seagrass Ecosystems}

Seagrass coverage: The coverage of seagrass at location 1 is about $65 \%$ of the area, 
while the seagrass covers $30 \%$ of the area of location 2 and 3 . The percentage of the seagrass covers at location 2 and three are classified into quite a good condition. The observation area at location 2 and 3 are used by fisherman activities such as fishery/aquaculture activity and tourism/community activity. While at location 1 the percentage of the seagrass covers is in very good condition, with the criteria adequate presence of beach ramps and stretch of coral area. Generally, this area is a beach that is managed to be a tourist location and a port of a traditional fishing boat. These activities, either directly or indirectly, will have an impact on the balance and sustainability of the seagrass ecosystem in the coastal region.

Waters brightness: the waters brightness in all study sites is in good condition with the brightness value is $>80 \%$ for all areas. Although at location 1 there are activities of the Teluk Bayur Port, as well as on location 2 Cindakir beach, these have not high impact in the decreasing of the brightness quality. This is because the scale of activity is not too big, i.e. small fishery cultivations. While on location 3 on Pasumpahan island, the waters brightness is not influenced by the activity of the community, where the location of the seagrass at location 3 is the place of the crossing ship between the island. This is the location where the tourist ships are docked daily.

Fish species: the fish population structure of the seagrass ecosystem can be explained by its species and family. The fish observed in the research location were classified into 17 species that are grouped into eight families (Table 2). Families of Gobiidae consists of 7 species, Chandidae consists of 2 species, and Fistulariidae, Apogonidae, Oryziidae, Atherinidae, Leiognathidae and Scatophagidae consist of 1 species. Based on the research Jones et al. (2017) the number of individuals of each species can explain the structure of the fish community on the ecosystem of the coastal waters. The result of data analysis of community structure of fish species on the seagrass ecosystem shows that ecologically there is no difference of fish community structure of all locations. In addition, the fish abundance in the seagrass ecosystem is influenced by the existence of the seagrass itself and also by the quality of environmental.

Seagrass species: based on observations at each location of research only found a species of Thalassia hemprichii. Kiswara (2009) explained that the type of Thalassia hemprichii is seagrass with vertical distribution up to 25 $m$ (depth). Also, this type of the seagrass can live in various types of subtrat ranging from muddy sand, medium-sized sand and rough to coral fragments.

Substrate type: types of substrate base of waters at location 1 of Nirvana beach is rough sand. While at the location 2 of Cindakir beach is sand and mud. Differently, the location 3 of Pasumpahan island is dominated by sand of coral. Putra et al. (2015) found that generally the substrate of waters in coastal Padang City is influenced by coastal morphology.

Current velocity: current velocity of beach in this research areas ranged between $0-0.17$ $\mathrm{m} /$ second and $0.17-0.34 \mathrm{~m} /$ second. The range of current velocity is very suitable for beach tourism activities. Based on the classification by Dean and Dalrymple (2004), the current velocity in the study areas can be classified into slow currents and fast currents.

Seagrass depth: Map of HydroOceanography of the Navy in 2011 was used to analyse the depth of the water for the existence of the seagrass ecosystem. The data shows that the depth of waters for the existence of the seagrass ecosystem in the study areas ranges from $0-3 \mathrm{~m}$ (Figure 2). Tanto et al. (2016) explained that the spatial approach to analysing this data can be used to predict waters depth for the seagrass ecosystem. The depth with value $0-5 \mathrm{~m}$ which is suitable for seagrass ecosystems in coastal waters of location 1 and 2 covers 15.4 ha, while this covers 8.00 ha at the location 3 of Pasumpahan island. 
Table 3. The result of Suitability Analysis for the Seagrass Ecotourism.

\begin{tabular}{|c|c|c|c|c|c|c|c|}
\hline Location & Parameter & Value & $\begin{array}{c}\text { Score } \\
\text { (S) }\end{array}$ & $\begin{array}{l}\text { Weight } \\
\text { (W) }\end{array}$ & $\mathrm{S}^{*} \mathbf{W}$ & Total & Category \\
\hline \multirow{7}{*}{1} & Seagrass coverage (\%) & $>50-75$ & 3 & 5 & 15 & \multirow{7}{*}{87} & \multirow{7}{*}{$\begin{array}{l}\text { Highly } \\
\text { suitable }\end{array}$} \\
\hline & Waters brightness $(\mathrm{m})$ & $>80$ & 4 & 4 & 16 & & \\
\hline & Fish species & $6-10$ & 3 & 4 & 12 & & \\
\hline & Seagrass species & $t^{*}$ & 2 & 4 & 8 & & \\
\hline & Substrate type & $\mathrm{cs}^{*}$ & 4 & 3 & 12 & & \\
\hline & Current velocity & $0-15$ & 4 & 3 & 12 & & \\
\hline & Seagrass depth & $1-3$ & 4 & 3 & 12 & & \\
\hline \multirow{7}{*}{2} & Seagrass coverage (\%) & $25-50$ & 2 & 5 & 10 & \multirow{7}{*}{76} & \multirow{7}{*}{ Suitable } \\
\hline & Waters brightness (m) & $>80$ & 4 & 4 & 16 & & \\
\hline & Fish species & $6-10$ & 3 & 4 & 12 & & \\
\hline & Seagrass species & $t^{\star}$ & 2 & 4 & 8 & & \\
\hline & Substrate type & $\mathrm{ms}^{*}$ & 2 & 3 & 12 & & \\
\hline & Current velocity & $0-15$ & 4 & 3 & 12 & & \\
\hline & Seagrass depth & $1-3$ & 4 & 3 & 12 & & \\
\hline \multirow{7}{*}{3} & Seagrass coverage (\%) & $25-50$ & 2 & 5 & 5 & \multirow{7}{*}{81} & \multirow{7}{*}{ Suitable } \\
\hline & Waters brightness $(\mathrm{m})$ & $>80$ & 4 & 4 & 16 & & \\
\hline & Fish species & $>10$ & 4 & 4 & 16 & & \\
\hline & Seagrass species & $t^{*}$ & 2 & 4 & 8 & & \\
\hline & Substrate type & $\mathrm{cs}^{*}$ & 4 & 3 & 12 & & \\
\hline & Current velocity & $0-15$ & 4 & 3 & 12 & & \\
\hline & Seagrass depth & $1-3$ & 4 & 3 & 12 & & \\
\hline
\end{tabular}

Note: $\mathrm{cs}^{*}$ coral sand, $\mathrm{ms}^{*}$ muddy sand, and $t^{*}$ thalassia hemprichii.
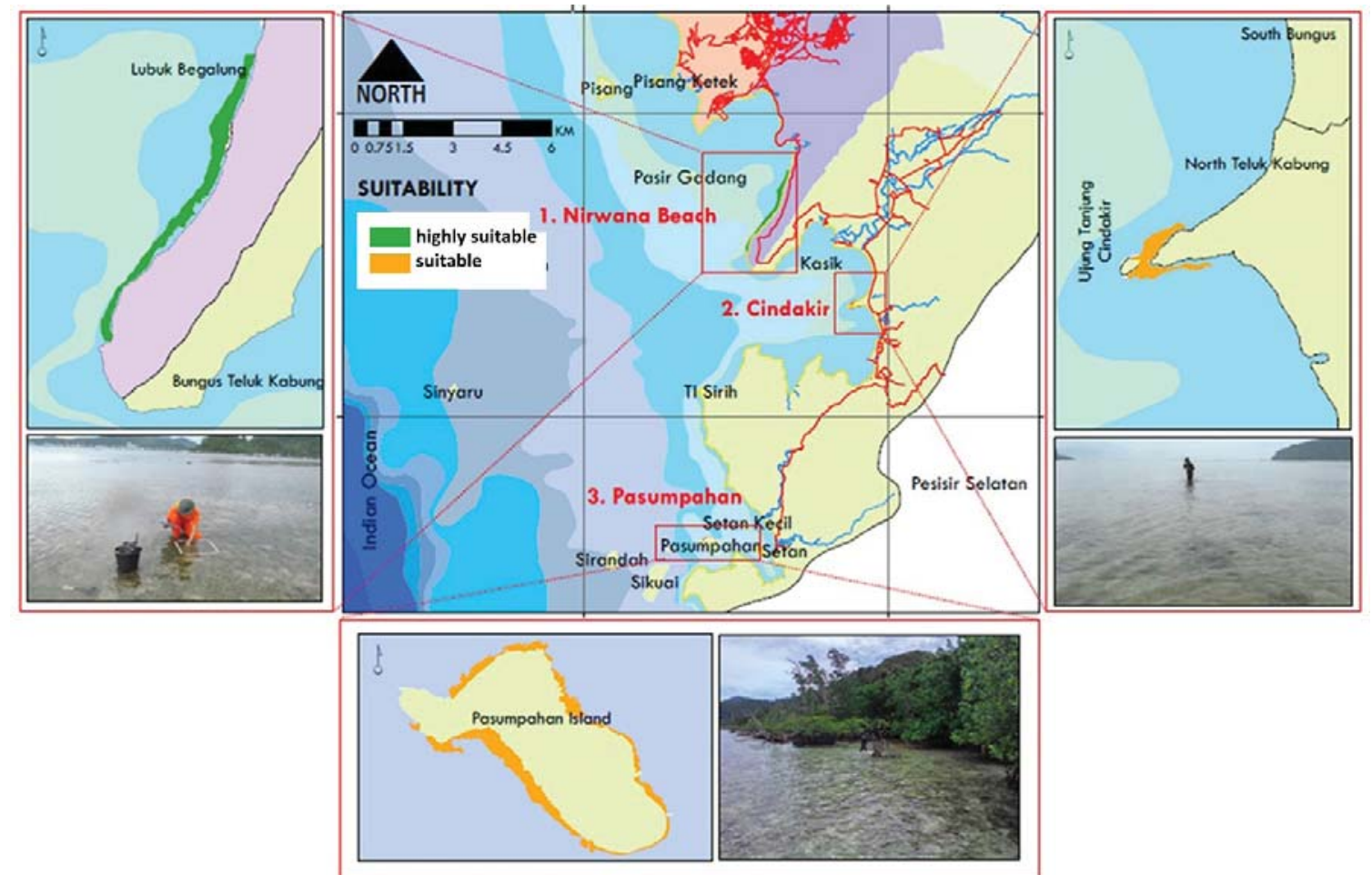

Figure 3. Map of Suitability the Seagrass Ecotourism in Padang City. 


\subsection{The Assessment of Seagrass Ecosystems for Marine Ecotourism}

The results of spatial analysis are presented in both tabular (Table 3) and spatial (Figure $3)$. Based on this analysis the location 1 of Nirwana beach reaches $84 \%$ of score that is highly suitable for seagrass ecotourism. The results indicate that the seagrass ecosystem at Nirwana beach can be recommended as a protected zone following the regulation from the Minister of Marine and Fisheries Number 23 (2016). This regulation stated that management of coastal region and small islands should take into account the ecological aspects of coastal resources for marine ecotourism. Fauzi et al. (2009) added that the conservation of protected areas are part of the coastal region that has specific characteristics should be protected and managed as unity. Differently, the location 2 of the Cindakir beach reach a value of $73 \%$ (suitable) which has a similar category with the location 3 (76\%). Putra et al. (2015) suggested that the damages of the seagrass ecosystem are suspected in this areas. These are caused by the impact of environmental degradation of the surrounding plateau and human activities that damaged the existing mangrove ecosystems around Cindakir beach area. Yulianda (2007) suggests that the damaged seagrass ecosystem can be recovered by rehabilitation using seagrass transplant. Meanwhile, the good condition of seagrass must be conserved to maintain the sustainability.

Based on the assessment of the suitability of the seagrass ecotourism in coastal waters and small islands of Padang City we suggest that the seagrass ecosystems can continue to grow as a marine ecotourism area in Padang City. This activity should be managed with attention to the ecological balance for the sustainability. It is expected that the potency of the seagrass ecosystem can be appropriately maintained both for conservation and ecotourism areas. The management also should pay attention to the potential threat to this ecosystem. Mainly, the current environmental condition brings the seagrass ecosystem to be prone to damage. The seagrass is facing a crisis due to various reasons including pressures from human activities in the coastal zone, the increasing of the frequency and intensity of natural disasters such as hurricanes, which may be indirectly associated with human activities (i.e. global warming) (Orth et al., 2006).

\section{Conclusion}

The research areas are commonly suitable for seagrass ecotourism with regards to the characteristics. Thalassia hemprichii is the only species that is found in the research location. The substrate of the waters is predominantly a sandy type of sand, except on Cindakir beach, where environmental activities and the local community cause the muddy sand substance. Although the locations are potential for further development of seagrass ecotourism, but much attention from the authority and community to maintain the sustainability and protect the ecosystem from damaged are strongly needed.

\section{Acknowledgements}

Thanks to Head of LRSDKP Bungus Padang who has provided support for this research and to Fredinan Yulianda as a key person from the Faculty of Fisheries and Marine Sciences, Bogor Agricultural University. We also express our gratitude to all people who have helped with the administration procedure as well as during the field survey.

\section{References}

Dean, R.G and R.A. Dalrymple. (2004). Coastal Processes With Engineering App. lication. Cambridge, United Kingdom: Cambridge University Press.

Fandeli, C. (2000). Pengertian dan konsep dasar ekowisata. Yogyakarta, Fakultas Kehutanan UGM.

Fauzi, Y., B. Susilo and Z.M. Mayasari. (2009). Analysis of Land Suitability of Coastal Area of Bengkulu City through Spatial Model Design and Geographic Information System (GIS). Forum Geografi, Vol. 23, No.1, pp. 101 - 111.

Haryati, S. (2010). Community Participation in Ecotourism Development in Pangandaran - West 
Java. Forum Geografi. Vol. 24, No. 1, pp. 12 - 27.

Hermon, D. (2016). The Strategic Model of Tsunami Based in Coastal Ecotourism Development at Mandeh Regions, West Sumatera, Indonesia. J. Environment and Earth Science. Vol. 6, No.4, pp. $40-45$.

Jones, I.T., Suca.T., Llopiz J and Mooney T.A. (2017). Characterizing soundscapes and larval fish settlement in tropical seagrass and mangrove habitats. The Journal of the Acoustical Society of America, Vol. 141 Issue 5, pp 4003 - 4003.

Kennish, M.J., S.M. Haag and G.P. Sakowicz. (2008). Seagrass Demographic and Spatial Habitat Characterization in Little Egg Harbor, New Jersey, Using Fixed Transects. J. Coastal Research. SI. 55, pp. $148-170$.

Kiswara, W. (2009). Seagrass Perspective in Coastal Biosafety. Jakarta: Presented at National Workshop I on Seagrass Ecosystem Management.

Kordi, M. (2011). Seagrass Ecosystem. Jakarta: Rineka Cipta Press.

Li, F., M. Xu., Q. Liu., Z. Wang and W. Xu. (2014). Ecological restoration zoning for a marine protected area: A case study of Haizhouwan National Marine Park, Cina. J. Ocean \& Coastal Management. SI. 89, pp. 158 - 166.

Marfai, M.A., A. Cahyadi and D.F. Anggraini. (2013). Typology, Dynamics, and Potential Disaster in the Coastal Karst Area Gunungkidul Regency. Forum Geografi. Vol. 27, No. 2, pp. 151 - 162.

Sugandi, D. (2013). Model of Conservation on Sagara Anakan Environmental. Forum Geografi. Vol. 27, No. 2, pp. $131-146$.

Tanto, T.A., A. Putra and Ilham (2014). Coastal Ecosystem Monitoring in Bungus Bay Area - Padang, West Sumatra. Proceedings of the National Marine Seminar 2014. pp. 27 - 41.

Tanto, T.A., S. Husrin., U.J. Wisha., A. Putra., R.K. Putri and Ilham. (2016). Characteristics of Physical Oceanography (Bathymetry, Tide, Wave Signifivant Height and Sea Current) in Bungus Bay. J. Kelautan. Vol. 9, No. 2, pp. $108-121$.

Taslim. A, R. Bohari and I.S. Arlyza. (2014). Analysis of SpaceSuitability Based on Marine Agriculture in The Small Islands Around Makassar. Forum Geografi. Vol. 28, No. 1, pp. 91 - 102.

Orth, R.J., Carruthers, T.TB., Dennison, W.C., Duarte, C.M., Fourqurean, J.W., Heck, K.L., Hughes, A.R., Kendrick, G.A., W. Kenworthy, WJ., Olyarnik, S., Short, F.T., Waycott, M., Williams, S.L. (2006). A Global Crisis for Seagrass Ecosystems, BioScience, Vol. 56, Issue 12, 1, pp 987 - 996.

Putra, A., T.A. Tanto and Ilham. (2015). Granules Size Analysis and Sedimentation Rate to Coral Reefs and Seagrass In The Bungus Bay Waters Padang City. Proceeding of International Conference on Green Development in Tropical Region 2015. pp. 89 - 97.

The Decision of the Ministry of Environmental of the Republic of Indonesia (2004). Damage Criteria and Guidelines for Seagrass Status Determination Number 200.

Director General of Legislation Regulation of the Ministry of Justice and Human Rights of the Republic of Indonesia. (2016). The Regulation of the Minister of Marine and Fisheries of the Republic of Indonesia No. 23/PERMEN-KP/2016 concerning "Management of Coastal Region and Small Islands". Jakarta.

Wardani, M. P. A., Fahrudin and F. Yulianda. (2017). Analysis of Successful Strategy to Develop Sustainable Marine Ecotourism in Gili Bawean Island, Gresik, East Java. IOP Conf. Series: Earth and Environmental Science, Vol 89, 012036, pp. 1 - 9.

Yulianda, F. (2007). Marine Ecotourism as an Alternative to Conservation - Based Coastal Resource Utilization. Science Seminar Papers February 21, 2007. Bogor: Department of Aquatic Resources Management Bogor Agricultural University. 